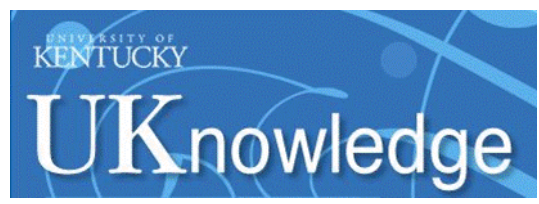

University of Kentucky

UKnowledge

7-1994

\title{
Nitrous Oxide Flux from Poultry-Manured Erosion Plots and Grass Filters after Simulated Rain
}

Mark S. Coyne

University of Kentucky, mark.coyne@uky.edu

R. A. Gilfillen

University of Kentucky

Robert L. Blevins

University of Kentucky

Follow this and additional works at: https://uknowledge.uky.edu/pss_facpub

Part of the Environmental Microbiology and Microbial Ecology Commons, and the Plant Sciences

Commons

Right click to open a feedback form in a new tab to let us know how this document benefits you.

\section{Repository Citation}

Coyne, Mark S.; Gilfillen, R. A.; and Blevins, Robert L., "Nitrous Oxide Flux from Poultry-Manured Erosion Plots and Grass Filters after Simulated Rain" (1994). Plant and Soil Sciences Faculty Publications. 14. https://uknowledge.uky.edu/pss_facpub/14

This Article is brought to you for free and open access by the Plant and Soil Sciences at UKnowledge. It has been accepted for inclusion in Plant and Soil Sciences Faculty Publications by an authorized administrator of UKnowledge. For more information, please contact UKnowledge@lsv.uky.edu. 
Nitrous Oxide Flux from Poultry-Manured Erosion Plots and Grass Filters after Simulated Rain

\section{Digital Object Identifier (DOI)}

http://dx.doi.org/10.2134/jeq1994.00472425002300040031x

Notes/Citation Information

Published in Journal of Environmental Quality, v. 23, no. 4, p. 831-834.

The copyright holder has granted the permission for posting the article here. 


\title{
Atmospheric Pollutants and Trace Gases
}

\author{
Nitrous Oxide Flux from Poultry-Manured Erosion Plots and \\ Grass Filters after Simulated Rain
}

\author{
M. S. Coyne, ${ }^{*}$ R. A. Gilfillen, and R. L. Blevins
}

\begin{abstract}
Adding carbon-rich materials to fields, like manure, may enhance denitrification. Grass filters, which are used to trap surface runoff from these fields, may also provide a carbon-rich environment that favors water infiltration and denitrification. Nitrous oxide $\left(\mathrm{N}_{2} \mathrm{O}\right)$ may be evolved in these settings. It is a radiatively important trace gas and intermediate in the denitrification pathway and several other microbial processes. We measured $\mathrm{N}_{2} \mathrm{O}$ flux, after simulated rain, using a soil cover technique in poultry-manured plots and grass filters receiving their runoff. Intact soil cores were used to relate the $\mathrm{N}_{2} \mathrm{O}$ flux to the denitrification potential of the plots. Nitrous oxide fluxes were smaller in grass filters than in manured plots, even though more denitrifying bacteria were present. The average $\mathrm{N}_{2} \mathrm{O}$ flux in the three most dynamic erosion plots was $755 \mu \mathrm{g} \mathrm{N}_{2} \mathrm{O}-\mathrm{N} \mathrm{m}^{-2} \mathrm{~h}^{-1}$, which was $39 \%$ of the maximal denitrification rate measured in acetylene-blocked, $\mathrm{NO}_{3}^{-}$-amended soil cores. Nitrous oxide flux immediately after rainfall was greater than $\mathrm{N}_{2} \mathrm{O}$ flux measurements reported for similar agricultural settings.
\end{abstract}

$\mathrm{A}^{\mathrm{s}}$ GRICULTURAL soILs in Kentucky are increasingly used to dispose of animal wastes from livestock production and processing facilities - particularly an expanding poultry (Gallus gallus domesticus) industry (Kentucky Agric. Stat., 1992, p. 59). One by-product of waste application to agricultural land is nitrate- $\mathrm{N}\left(\mathrm{NO}_{3}^{-}\right)$, due to mineralization and nitrification. If $\mathrm{NO}_{3}^{-}$is formed in excess of crop uptake, it can contribute to groundwater contamination after transport in surface water runoff.

Grass filters are used to control runoff from agricultural land (Gross et al., 1991). They remove some of the soluble nutrients, like $\mathrm{NO}_{3}^{-}$, which are intercepted during surface flow. Groffman et al. (1991) found that denitrification in grass filters removed 14 to $25 \%$ of the $\mathrm{NO}_{3}^{-}$applied depending on the grass variety. If additional $\mathrm{C}$ was added, the potential $\mathrm{NO}_{3}^{-}$removal by denitrification increased. They suggested that runoff containing available $C$, in addition to $\mathrm{NO}_{3}^{-}$, such as runoff from manure-amended fields, might promote greater denitrification in grass filters than runoff poor in C.

If denitrification were promoted in grass filters, nitrous oxide $\left(\mathrm{N}_{2} \mathrm{O}\right)$ evolution could also increase, because it is one of the principle intermediates in the denitrification pathway (Firestone, 1982). Because $\mathrm{N}_{2} \mathrm{O}$ may contribute to global warming and atmospheric ozone destruction, information about its sources in agricultural settings is important for modeling global $\mathrm{N}_{2} \mathrm{O}$ flux. It is particularly

Department of Agronomy, N-122 Agricultural Science Building North, Univ. of Kentucky, Lexington, KY 40546-0091. Received 13 May 1993. *Corresponding author (mscoyn00@ukcc.uky.edu).

Published in J. Environ. Qual. 23:831-834 (1994). important to obtain flux measurements when $\mathrm{N}_{2} \mathrm{O}$ evolution is most dynamic - such as immediately after rainfall.

We measured $\mathrm{N}_{2} \mathrm{O}$ flux after simulated rain in poultry manured soil and grass filters receiving their runoff. Our goal was to assess the $\mathrm{N}_{2} \mathrm{O}$ flux in poultry-manured soil immediately after rain in comparison to reported $\mathrm{N}_{2} \mathrm{O}$ flux measurements from similar agricultural settings. We also wanted to assess $\mathrm{N}_{2} \mathrm{O}$ flux from grass filters receiving the runoff from these poultry-manured fields.

\section{MATERIALS AND METHODS}

Site. This study was done at the University of Kentucky Agricultural Experiment Station in Lexington during June and July 1992. Experimental plots were on a Maury silt loam soil (fine, mixed, mesic Typic Paleudalf) with an average natural slope of $9 \%$ and soil permeability ranging from 5 to $15 \mathrm{~cm} \mathrm{~h}^{-1}$ (Blevins et al., 1990). Six individual erosion plots $4.6 \mathrm{~m}$ wide by $22.1 \mathrm{~m}$ long were used (Fig. 1). A grass filter either $4.5 \mathrm{~m}$ or $9.0 \mathrm{~m}$ in length abutted each erosion plot. Grass filters were a mixed sod composed of tall fescue (Festuca arundinacea L.) and 'Kentucky' bluegrass (Poa pratensis L.). For 8 continuous years before this study, the tillage management used on these plots was conventional tillage in Plots 1 and 3, no-tillage in Plots 2 and 4, and chisel plow tillage in Plots 3 and 6. In 1992, the tillage management in all plots was chisel plow tillage.

Site Treatment. Poultry litter mixed with sawdust and wood shavings bedding from a breeder house was briefly stockpiled and then uniformly spread over each erosion plot on 29 June 1992 at $16.5 \mathrm{Mg} \mathrm{ha}^{-1}$ (wet wt.). The poultry litter contained $2.8 \%$ total $\mathrm{N}, 2.93 \%$ total $\mathrm{P}$, and $1.78 \%$ total $\mathrm{K}$ (wet basis) at a moisture content of $34.2 \%$. Poultry litter was partially incorporated into each plot with a chisel plow as the only tillage practice. Erosion plots were covered with black plastic tarps to protect them from natural rain but which allowed air circulation. Grass filters were not covered.

On 1, 7, 9, 14, 16, or 21 July 1992, rain was simulated on one of the erosion plots beginning with Plot 1 . The plastic tarp was removed and simulated rain was delivered to each erosion plot at about $6.4 \mathrm{~cm} \mathrm{~h}^{-1}$. This intensity approximates a 1-in-10yr storm event in central Kentucky. A storm of such intensity occurred in Lexington on $16 \mathrm{July} 1992$ (Fig. 2). Moore et al. (1983) have previously described the rain simulator used in our study.

The duration of simulated rainfall varied from plot to plot, because each erosion plot had different runoff characteristics, and because simulated rain continued until runoff was measured for at least $1 \mathrm{~h}$ at the bottom of grass filters with two different lengths (Fig. 1). Consequently, simulated rain lasted for $115 \mathrm{~min}$ in Plot 1,135 min in Plot 2, $140 \mathrm{~min}$ in Plot 3,136 min in Plot 4, $100 \mathrm{~min}$ in Plot 5, and $110 \mathrm{~min}$ in Plot 6. Surface runoff from

Abbreviations: ECD, electron capture detector; TCD, thermal conductivity detector; MPN, most probable number. 


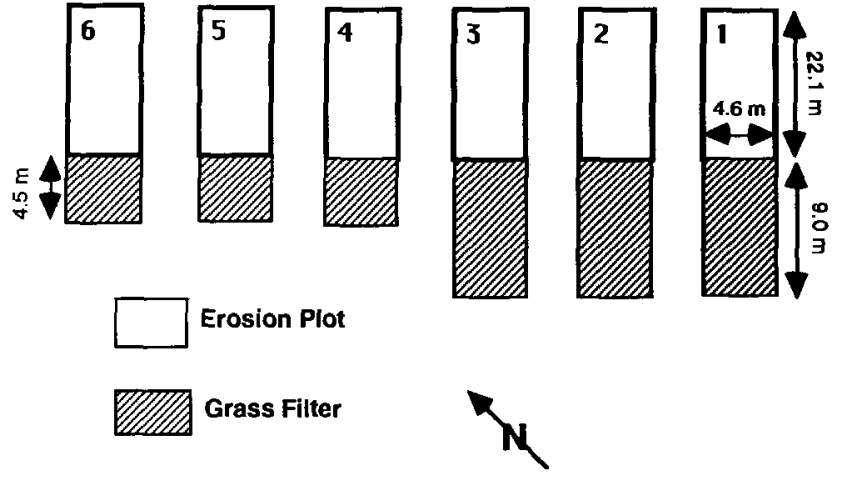

Fig. 1. Diagram of the study plots.

the erosion plots was usually observed 20 to 30 min after simulated rain began.

Soil Cover Measurements. After simulated rain ceased, soil covers were immediately inserted to a depth of $2.5 \mathrm{~cm}$ in the middle of the erosion plot. The soil covers placed in the grass filters were within $1 \mathrm{~m}$ of the erosion plots; this location became saturated by surface runoff during simulated rain. The soil covers were coffee cans $17.1 \mathrm{~cm}$ high by $15.6 \mathrm{~cm}$ diam. with the bottoms removed and a rubber septum penetrating the original plastic lid. Preliminary experiments with $\mathrm{N}_{2} \mathrm{O}$ indicated that the cans remained gas tight for the duration of field measurements (data not shown). Five replicates were used at each location. At 0-, 15-, 30-, and 60-min intervals, gas samples were removed from the soil cover head space and stored in preevacuated Vacutainers (Beckton Dickinson, Rutherford, $\mathrm{NJ}$ ) for $\mathrm{N}_{2} \mathrm{O}$ analysis.

Intact Core Denitrification Measurements. Five, randomly distributed, intact soil cores $15 \mathrm{~cm}$ in depth were collected from each erosion plot and grass filter strip in $21 \mathrm{~cm}$ high by $2.5 \mathrm{~cm}$ diam. plastic sleeves about 1 mo after simulated rainfall studies. The cores were saturated with $10 \mathrm{mM} \mathrm{KNO}_{3}$ and allowed to stand for $30 \mathrm{~min}$ before excess solution was drained and the plastic sleeve sealed at both ends with sleeve-type rubber stoppers. The head space was evacuated and flushed three times with $\mathrm{N}_{2}$. Ten milliliters of head space gas were removed and replaced by an equal volume of reagent-grade acetylene. One-milliliter gas samples were removed from the head space at $0-, 2-$, and 6-h intervals.

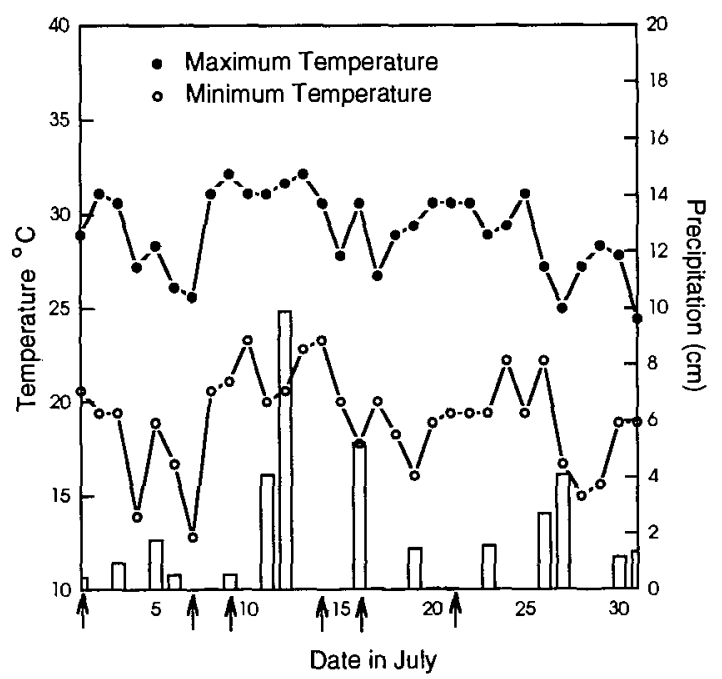

Fig. 2. Precipitation and average daily temperatures during the study (arrows indicate dates of rain simulations).
Gas Analysis. Gas samples were analyzed for $\mathrm{N}_{2} \mathrm{O}$ on a Varian 3700 gas chromatograph with $2 \mathrm{~m}$ Porapak $\mathrm{Q}$ columns using an electron capture detector (ECD) for soil cover samples and a thermal conductivity detector (TCD) for intact cores. Analysis conditions for the ECD were: detector temperature, $360^{\circ} \mathrm{C}$; column temperature, $60^{\circ} \mathrm{C}$; carrier gas, $95 \%$ argon, $5 \%$ meth-

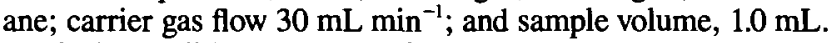
Analysis conditions for the TCD were: detector temperature, $120^{\circ} \mathrm{C}$; filament temperature, $140^{\circ} \mathrm{C}$; column temperature, $60^{\circ} \mathrm{C}$; carrier gas, helium; carrier gas flow rate, $35 \mathrm{~mL} \mathrm{~min}^{-1}$; and sample volume $1.0 \mathrm{~mL}$. Machine response to $\mathrm{N}_{2} \mathrm{O}$ was measured and compared to standard curves for $\mathrm{N}_{2} \mathrm{O}$ generated from gas standards of known concentration.

Chemical Analyses. Chemical analysis of poultry litter was done in the University of Kentucky Regulatory Services soil testing lab. Soil samples for chemical characterization were taken from the 0 - to 15 -cm depth interval in both the erosion plots and the grass filters before addition of poultry litter. The $\mathrm{pH}$ was measured in a 1:1 soil/water slurry. Percent soil $\mathrm{C}$ was measured on a CR 12 Leco Carbon Determinator (Leco Corp., St. Joseph, MI).

Microbial Analysis. Soil samples used to determine denitrifier most probable number (MPN) were removed from the 0 - to 15 cm depth interval in both the erosion plots and the grass filters about $24 \mathrm{~h}$ after rain simulation in each plot. The denitrifier MPN in erosion.plots and grass filters was determined as outlined by Tiedje (1982). A 10-fold serial dilution of soil in physiological saline $\left(8 \mathrm{~g} \mathrm{~L}^{-1} \mathrm{NaCl}\right.$ in distilled $\mathrm{H}_{2} \mathrm{O}$ ) was used to inoculate five replicate tubes per dilution. Growth media was Tryptic Soy Broth with $1 \mathrm{~g} \mathrm{~L}^{-1} \mathrm{KNO}_{3}$. The tubes were incubated $28 \mathrm{~d}$ at $26^{\circ} \mathrm{C}$ and residual $\mathrm{NO}_{3}^{-}$was detected with diphenylamine in concentrated sulfuric acid. The MPN of denitrifiers were determined using published tables (Alexander, 1982).

Statistical Analysis. ANOVA and $t$-tests were made using the CoStat (CoHort Software, Berkeley, CA) statistical software package for personal computers.

\section{RESULTS AND DISCUSSION}

Nitrous oxide flux rates immediately after simulated rain were greater in the erosion plots than they were in the grass filters $(\alpha=0.05$; Table 1$)$. The average coefficient of variation in flux rates between plots was $56 \%$ in erosion plots (range $25-100 \%$ ) and $91 \%$ in grass filters (range 36-131\%). This spatial variability is not unique for $\mathrm{N}_{2} \mathrm{O}$ field measurements (Goodroad et al., 1984; Mosier et al., 1986). The average $\mathrm{N}_{2} \mathrm{O}$ flux rate in Plots 1,2 , and $3(775 \mu \mathrm{g}$ $\mathrm{N}_{2} \mathrm{O}-\mathrm{N} \mathrm{m}^{-2} \mathrm{~h}^{-1}$ ), the first plots treated, was greater than the average $\mathrm{N}_{2} \mathrm{O}$ flux rate in Plots 4, 5, and $6(134 \mu \mathrm{g}$ $\mathrm{N}_{2} \mathrm{O}-\mathrm{N} \mathrm{m}^{-2} \mathrm{~h}^{-1} ; \alpha=0.05$ ). We did not find this difference in the grass filters.

Nitrous oxide fluxes have been measured in numerous environments. Based on an evaluation of various field experiments, Eichner (1990) estimated that $2 \%$ of $N$ fertilizer is lost as $\mathrm{N}_{2} \mathrm{O}$ over a 1-yr period in fertilized and manured soils. Average daily flux was $24 \mu \mathrm{g} \mathrm{N}_{2} \mathrm{O}-\mathrm{N} \mathrm{m}^{-2} \mathrm{~h}^{-1}$ from ammonium-fertilized grass and $7 \mu \mathrm{g} \mathrm{N} \mathrm{N}_{2} \mathrm{O}-\mathrm{N} \mathrm{m}^{-2} \mathrm{~h}^{-1}$ from soil (Eichner, 1990). The $\mathrm{N}_{2} \mathrm{O}$ flux immediately after rain in poultry-manured soils suggests that this flux could be much greater, albeit, for a short period. The flux rates we measured may underestimate the true $\mathrm{N}_{2} \mathrm{O}$ flux rate due to the solubility of $\mathrm{N}_{2} \mathrm{O}$ in water. Nitrous oxide has an adsorption coefficient between 0.544 and $0.472 \mathrm{~mL}$ $\mathrm{N}_{2} \mathrm{O}$ per $\mathrm{mL}$ of water from 25 to $30^{\circ} \mathrm{C}$ (Tiedje, 1982); 
Table 1. Mean $\mathrm{N}_{2} \mathrm{O}$ evolution immediately after simulated rainfall in poultry-manured erosion plots and grass filters receiving their runoff.

\begin{tabular}{lccc}
\hline Plot & $\begin{array}{c}\text { Days after } \\
\text { litter applied }\end{array}$ & Erosion plot $\dagger$ & Grass filter \\
\hline & & & $\mu \mathrm{N}_{2} \mathrm{O}-\mathrm{N} \mathrm{m}^{-2} \mathrm{~h}^{-1}$ \\
1 & 2 & $1000 \pm 527$ & $148 \pm 177$ \\
2 & 8 & $559 \pm 191$ & $58 \pm 76$ \\
3 & 10 & $763 \pm 581$ & $85 \pm 44$ \\
4 & 15 & $51 \pm 51$ & $79 \pm 57$ \\
5 & 17 & $201 \pm 51$ & $76 \pm 83$ \\
6 & 22 & $76 \pm 83$ \\
\hline
\end{tabular}

$\dagger$ Mean of five soil covers \pm 1 SD.

this range spans the soil temperatures observed during flux measurements.

Goodroad et al. (1984) found a mean $\mathrm{N}_{2} \mathrm{O}$ flux from a manure-amended, no-till corn (Zea mays L.) experiment in Wisconsin of about $100 \mu \mathrm{g} \mathrm{N}_{2} \mathrm{O}-\mathrm{N} \mathrm{m}^{-2} \mathrm{~h}^{-1}$. However, during spring thaw, when soils were presumably saturated, $\mathrm{N}_{2} \mathrm{O}$ flux reached $634 \mu \mathrm{g} \mathrm{N} \mathrm{N}_{2} \mathrm{O}-\mathrm{N} \mathrm{m}^{-2} \mathrm{~h}^{-1}$. A period in their study, comparable to conditions we created with our rainfall simulation, occurred during the first rainfall after manure addition to soil. Goodroad et al. (1984) measured a $\mathrm{N}_{2} \mathrm{O}$ flux of about $400 \mu \mathrm{g} \mathrm{N} 2 \mathrm{O}-\mathrm{N} \mathrm{m}^{-2} \mathrm{~h}^{-1}$. This is comparable to the average $\mathrm{N}_{2} \mathrm{O}$ flux rates we observed in our first three plots after simulated rain. Mosier et al. (1986) observed that, in irrigated corn fertilized with $200 \mathrm{~kg} \mathrm{~N}$ $\mathrm{ha}^{-1}$ as $\mathrm{NH}_{4} \mathrm{SO}_{4}, \mathrm{~N}_{2} \mathrm{O}$ emissions peaked at 565 and 504 $\mu \mathrm{g} \mathrm{N}_{2} \mathrm{O}-\mathrm{N} \mathrm{m}^{-2} \mathrm{~h}^{-1}$ after a $7.8-\mathrm{cm}$ and $7.0-\mathrm{cm}$ rain, respectively.

Nitrous oxide may be evolved during autotrophic and heterotrophic nitrification (Robertson and Tiedje, 1987) and $\mathrm{NO}_{3}^{-}$respiration (Smith and Zimmerman, 1981) as well as during denitrification. We cannot rule out the first three processes as the source of $\mathrm{N}_{2} \mathrm{O}$ because we did not selectively inhibit them (Robertson and Tiedje, 1987). However, the intensity and duration of rainfall would have created soil conditions favorable for denitrification.

The $\mathrm{NO} / \mathrm{N}_{2} \mathrm{O}$ ratio may also be a useful indicator of whether $\mathrm{N}$-oxide flux comes from denitrification or some other process (Davidson, 1991). Anderson and Levine (1986) found that the $\mathrm{NO} / \mathrm{N}_{2} \mathrm{O}$ ratio was 0.01 to 0.3 for denitrifiers and 0.9 to 5.6 for nitrifiers and $\mathrm{NO}_{3}^{-}$respirers. The Vacutainers used for gas sampling were contaminated with NO. However, even with this background NO, the $\mathrm{NO} / \mathrm{N}_{2} \mathrm{O}$ ratio was $<0.01$ (data not shown), which suggests that, initially, denitrification was the main source of $\mathrm{N}_{2} \mathrm{O}$ from these plots.

What could account for the different flux rates between the erosion plots and grass filters, and the dramatic difference in $\mathrm{N}_{2} \mathrm{O}$ flux rates between the first three erosion plots and the last three? We suspected that if denitrification were a major $\mathrm{N}_{2} \mathrm{O}$ source, different denitrifier population size might be responsible. When examined, Plots 1,2 , and 3 had 10 -fold greater denitrifier MPN than Plots 4,5 , and 6 (Table 2). We believe this difference may be because erosion Plots 4, 5, and 6 were covered for an extended period by a plastic tarp when maximum daily temperatures exceeded $27^{\circ} \mathrm{C}$ (Fig. 2). However, we did not
Table 2. Chemical and biological differences between erosion plots and grass filters.

\begin{tabular}{lcccccc}
\hline & \multicolumn{2}{c}{$\begin{array}{c}\text { Average of } \\
\text { Plots 1, 2, and 3 }\end{array}$} & & \multicolumn{2}{c}{$\begin{array}{c}\text { Average of } \\
\text { Plots 4, 5, and 6 }\end{array}$} \\
\cline { 2 - 3 } \cline { 6 - 7 } Soil property & $\begin{array}{c}\text { Erosion } \\
\text { plot }\end{array}$ & $\begin{array}{c}\text { Grass } \\
\text { filter }\end{array}$ & & $\begin{array}{c}\text { Erosion } \\
\text { plot }\end{array}$ & $\begin{array}{c}\text { Grass } \\
\text { filter }\end{array}$ \\
\hline $\begin{array}{l}\text { pH } \\
\%\end{array}$ & 5.5 & $6.7^{*}$ & & 5.7 & $6.6^{*}$ \\
$\begin{array}{l}\text { MPN } \dagger \\
\text { Denitrifiers }\end{array}$ & 2.08 & 1.93 & & 1.98 & 1.97 \\
\hline
\end{tabular}

- Indicates a difference between the erosion plot and grass filter in each group of plots ( $t$-test, $a=.05$ ).

+ MPN (most probable number) of denitrifiers $\mathrm{g}^{-1}$ oven dry soil. The $95 \%$ confidence interval is $\pm 3.3 \times$ MPN.

test this hypothesis by comparing pre- and postexperiment denitrifier MPN.

The grass filters were not covered during the experiment, yet we also found a difference in the average denitrifier MPN of Plots 1, 2, and 3 and Plots 4, 5, and 6. If intrinsic soil properties varied across the experiment site from Plot 1 to Plot 6, they were not among the parameters we measured. Neither $\mathrm{pH}$ nor \% C differed significantly across erosion plots or across grass filters (Table 2).

Grass filters had 100 -fold greater denitrifier MPN and greater $\mathrm{pH}$ than erosion plots $(\alpha=0.05$; Table 2$)$. So, denitrifier population size is an unsatisfactory explanation for the differences in $\mathrm{N}_{2} \mathrm{O}$ flux rates between erosion plots and grass filters. A better explanation is that more $\mathrm{NO}_{3}^{-}$ or $\mathrm{NH}_{4}^{+}$was available in the erosion plots than the grass filters. In 1991, all erosion plots were fertilized with 170 $\mathrm{kg} \mathrm{N} \mathrm{ha}{ }^{-1}$ as $\mathrm{NH}_{4} \mathrm{NO}_{3}$ and subjected to at least two separate rate simulations. The poultry manure we added to each erosion plot in 1992 contained about $304 \mathrm{~kg} \mathrm{~N} \mathrm{ha}^{-1}$. Fresh poultry manure typically consists of 25 to $30 \%$ urea and ammonium forms (Rasnake et al., 1991), some of which would have been lost by volatilization under the plastic tarps. The remaining ammonium and mineralizable $\mathrm{N}$ forms would nitrify over time.

We did not measure soil $\mathrm{NO}_{3}^{-}$and $\mathrm{NH}_{4}^{+}$concentrations either before or after rain simulation. However, we measured $\mathrm{NO}_{3}^{-}$concentrations in surface runoff. The maximal $\mathrm{NO}_{3}^{-}$concentration in surface runoff from erosion plots increased from Plot 1 to 6 . This corresponds with the order in which simulations were done (Table 3). The only source of $\mathrm{N}$ added to the grass filters was runoff from the erosion plots. The final $\mathrm{NO}_{3}^{-}$concentration in surface runoff from the erosion plots immediately before $\mathrm{N}_{2} \mathrm{O}$ flux measurements began was greater than in grass filters

Table 3. Concentration of $\mathrm{NO}_{3}^{-}-\mathrm{N}$ in surface runoff.

\begin{tabular}{|c|c|c|c|c|c|}
\hline \multirow[b]{2}{*}{ Plot } & \multirow[b]{2}{*}{$\begin{array}{c}\text { Days after } \\
\text { litter applied }\end{array}$} & \multicolumn{2}{|c|}{ Maximal } & \multicolumn{2}{|c|}{ Final } \\
\hline & & $\begin{array}{c}\text { Erosion } \\
\text { plot }\end{array}$ & $\begin{array}{l}\text { Grass } \\
\text { filter }\end{array}$ & $\begin{array}{c}\text { Erosion } \\
\text { plot }\end{array}$ & $\begin{array}{l}\text { Grass } \\
\text { filter }\end{array}$ \\
\hline & & & $\mathbf{m g ~ N}$ & $\mathrm{NL}^{-1}$ & \\
\hline 1 & 2 & 0.53 & 0.56 & 0.52 & 0.42 \\
\hline 2 & 8 & 0.73 & 0.57 & 0.57 & 0.50 \\
\hline 3 & 10 & 1.02 & 0.45 & 0.39 & 0.38 \\
\hline 4 & 15 & 1.12 & 1.15 & 0.43 & 0.43 \\
\hline 5 & 17 & 0.69 & 0.64 & 0.49 & 0.43 \\
\hline 6 & 22 & 1.50 & 0.55 & 0.59 & 0.36 \\
\hline
\end{tabular}


Table 4. Mean $\mathrm{N}_{2} \mathrm{O}$ evolution in acetylene-blocked, $\mathrm{NO}_{3}^{-}$-amended, intact soil cores from erosion plots and grass filters.

\begin{tabular}{|c|c|c|}
\hline Plot & Erosion plot & Grass filter \\
\hline & -1 & 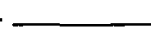 \\
\hline $\begin{array}{l}1 \\
2 \\
3 \\
4 \\
5 \\
6\end{array}$ & $\begin{aligned} 393 & \pm 596 \\
2590 & \pm 3580 \\
2750 & \pm 2810 \\
3840 & \pm 7850 \\
190 & \pm 279 \\
112 & \pm 155\end{aligned}$ & $\begin{aligned} & 297 \pm 483 \\
& 4810 \pm 4310 \\
& 2710 \pm 1260 \\
& 557 \pm 1250 \\
& 629 \pm 818 \\
& \mathrm{ND} \ddagger\end{aligned}$ \\
\hline
\end{tabular}

$\dagger$ Mean of five cores \pm 1 SD.

$\ddagger \mathrm{ND}=$ no data.

( $\alpha=0.05$; Table 3 ). This evidence, along with the fertilization history of the erosion plots, suggests that the erosion plots contained more available $\mathrm{NO}_{3}^{-}$than the grass filters at the start of $\mathrm{N}_{2} \mathrm{O}$ flux measurements.

Was the potential $\mathrm{N}_{2} \mathrm{O}$ flux from an erosion plot simply greater than in a grass filter? If part of the $\mathrm{N}_{2} \mathrm{O}$ flux were associated with denitrification activity, denitrification potential in erosion plots and grass filters should reflect the different $\mathrm{N}_{2} \mathrm{O}$ flux rates observed. Intact soil cores were removed from erosion plots and grass filters to test this hypothesis.

The coefficients of variation were considerably greater in our intact core studies than they were in our field measurements. The average coefficient of variation was $147 \%$ for erosion plot cores (range 102-205\%) and $131 \%$ for grass filter cores (range 47-224\%). There was no significant difference between the denitrification potential of the two sets of cores $(\alpha=0.05$; Table 4$)$.

The average $\mathrm{N}_{2} \mathrm{O}$ flux from erosion Plots 1,2 , and 3 , $755 \mu \mathrm{g} \mathrm{N}_{2} \mathrm{O}-\mathrm{N} \mathrm{m}^{-2} \mathrm{~h}^{-1}$, was equivalent to $39 \%$ of the average total $\mathrm{N}$-flux we observed in $\mathrm{NO}_{3}^{-}$-amended, acetylene blocked, intact cores from Plots 1, 2, and 3 (Tables 1 and 4). In contrast, the average $\mathrm{N}_{2} \mathrm{O}$ flux from the grass filters in Plots 1, 2, and 3, $97 \mu \mathrm{g} \mathrm{N} \mathrm{N}_{2} \mathrm{O}-\mathrm{N} \mathrm{m}^{-2} \mathrm{~h}^{-1}$, was only $4 \%$ of the average total $\mathrm{N}$ gas flux under acetylene blocked conditions. Groffman et al. (1991) suggested that surface runoff from manured soils might carry sufficient $\mathrm{C}$ to enhance denitrification in adjacent grass filters, thus removing $\mathrm{NO}_{3}^{-}$before it reaches groundwater. If denitrifying conditions were created in the grass filters, the smaller $\mathrm{N}_{2} \mathrm{O}$ flux rates may simply be due to more $\mathrm{N}_{2}$ production than in the corresponding erosion plots.

\section{CONCLUSION}

If an accurate estimate of agricultural $\mathrm{N}_{2} \mathrm{O}$ input to global $\mathrm{N}_{2} \mathrm{O}$ flux is to be made, models of global atmospheric $\mathrm{N}_{2} \mathrm{O}$ flux from agricultural soils must account for $\mathrm{N}_{2} \mathrm{O}$ flux in soils undergoing wetting and drying cycles. Nitrous oxide flux immediately after rainfall can exceed $1 \mathrm{mg} \mathrm{m}^{-2} \mathrm{~h}^{-1}$ for an indeterminate period in poultry manure-amended fields. More refined field studies are needed to demonstrate the source of $\mathrm{N}_{2} \mathrm{O}$ evolved in these settings. If the major $\mathrm{N}_{2} \mathrm{O}$ source is denitrification, further research must demonstrate whether denitrification in grass filter strips is enhanced by the $C$ contained in surface runoff from adjacent manured fields.

\section{ACKNOWLEDGMENTS}

We thank Roger Rhodes, C. Elizabeth Madison, and Jan Shuler for their assistance during rain simulation and Abigail Hightshoe and Murali Murageshi for their technical assistance during laboratory assays. This research was supported by Grant No. 432271 from the Kentucky Water Resources Research Institute with additional support provided by Kentucky State Senate Bill 271. It is published with permission of the Director of the Kentucky Agricultural Experiment Station as journal article no. 93-3-47.

\section{REFERENCES}

Alexander, M. 1982. Most probable number method for microbial populations. p. 815-820. In A.L. Page et al. (ed.) Methods of soil analysis. Part 2. 2nd ed. Agron. Monogr. 9. ASA and SSSA, Madison, WI.

Anderson, I.C., and J.S. Levine 1986. Relative rates of nitric oxide and nitrous oxide production by nitrifiers, denitrifiers, and nitrate respirers. Appl. Environ. Microbiol. 51:938-945.

Blevins, R.L., W.W. Frye, P.L. Baldwin, and S.D. Robertson. 1990. Tillage effects on sediment and soluble nutrient losses from a Maury silt loam soil. J. Environ. Qual. 19:683-686.

Davidson, E. 1991. Fluxes of nitrous oxide and nitric oxide from terrestrial ecosystems, p. 219-235. In J.E. Rogers and W.B. Whitman (ed.) Microbial production and consumption of greenhouse gases. Am. Soc. of Microbiol., Washington, DC.

Eichner, M.J. 1990. Nitrous oxide emissions from fertilized soils: Summary of available data. J. Environ. Qual. 19:272-280.

Firestone, M.K. 1982. Biological denitrification. p. 289-326. In F.J. Stevenson (ed.) Nitrogen in agricultural soils. Agron. Monogr. 22. ASA, CSSA, and SSSA, Madison, WI.

Goodroad, L.L., D.R. Keeney, and L.A. Peterson. 1984. Nitrous oxide emissions from agricultural soils in Wisconsin. J. Environ. Qual. 13:557-561.

Groffman, P.M., E.A. Axelrod, J.L. Lemunyon, and W. Michael Sullivan. 1991. Denitrification in grass and forest vegetated filter strips. J. Environ. Qual. 20:671-674.

Gross, C.M., J.S. Angle, R.L. Hill, and M.S. Welterlen. 1991. Runoff and sediment losses from tall fescue under simulated rainfall. J. Environ. Qual. 20:604-607.

Kentucky Agricultural Statistics Service. 1992. Kentucky agricultural statistics, 1991-1992. Kentucky Agric. Statistics Service, Louisville, KY.

Moore, I.D., M.C. Hirschi, and B.J. Barfield. 1983. Kentucky rainfall simulator. Trans. ASAE 26:1085-1089.

Mosier, A.R., W.D. Guenzi, and E.E. Schweizer. 1986. Soil losses of dinitrogen and nitrous oxide from irrigated crops in northeastern Colorado. Soil Sci. Soc. Am. J. 50:344-348.

Rasnake, M., L. Murdock, and W.O. Thom. 1991. Using poultry litter on agricultural land. Kentucky Coop. Ext. Ser. Bull. AGR-156.

Robertson, G.P., and J.M. Tiedje. 1987. Nitrous oxide sources in aerobic soils: Nitrification, denitrification, and other biological processes. Soil Biol. Biochem. 19:187-193.

Smith, M.S., and K. Zimmerman. 1981. Nitrous oxide production by nondenitrifying soil nitrate reducers. Soil Sci. Soc. Am. J. 45:865-871.

Tiedje, J.M. 1982. Denitrification. p. 1011-1026. In A.L. Page et al. (ed.) Methods of soil analysis. Part 2. 2nd ed. Agron. Monogr. 9. ASA and SSSA, Madison, WI. 